\title{
Understanding Japanese Policy for Malaya from the Perspective of Nihonjinron
}

\author{
Ong Sheau Wen \\ Faculty of Arts and Social Science, \\ Universiti Tunku Abdul Rahman, Kampar, Perak \\ e-mel: swong@utar.edu.my \\ DOI: https://doi.org/10.37134/ejoss.vol5.1.5.2019
}

\begin{abstract}
An examination of Japan in search of national character can be traced back to its modernization in Meiji Era and as recent as post-war period. Japan sought to articulate national identity because of tainted Japanese minds by wicked Occident ideas. In this context, the notion of Nihonjinron and its distinctive characteristics are central to grasp Japan's thoughts and behaviors vis-à-vis dominant Western culture. During Japan's occupation of Malaya in 194145, the promulgation of its wartime propaganda to create "Asia for the Asiatic" and to exterminate imperialist Western power from the "Greater East Asia Co-Prosperity Sphere" had a considerable impact on Malayan political development. The occupation accelerated the drive towards Malayan independence amid repeated racial clashes. This paper is a conceptual attempt to unravel Japanese nationalist doctrines, rooted in Nihonjinron discourse that not only underpinned its Occident worldview throughout the course of war but also became the underpinning ofits propaganda machine.The significance of this study lies in its effort to offer an alternative way of interpreting Japanese occupation of Malaya from the perspective of Nihonjinron. It has important implications for understanding how the construction of Japanese image affects its relationship with Malaysia in the post-war period.
\end{abstract}

Keywords: Japanese nationalism, Nihonjinron, ideology, propaganda

\section{INTRODUCTION}

Meiji Restoration (1868-1912) was an important turning point in Japan's history. The consecutive victories in the Sino-Japanese War of 1894-1895 and the Russo-Japanese War of 1904-1905 buoyed up the nation's self-confidence. Coupled with the revival of ancient Shinto belief and the restoration of Imperial system, Japan was basked in the glory of international prestige and its national identity was clothed in militaristic configuration of nationalism, which turned into the crux of wartime ideology until the end of the Pacific War. The heightened nationalism also explained much of Imperial Japanese Army selflessness devotion to war effort and Japan's imperial expansion into Southeast Asia.

The success of Imperial Japanese Army at the initial stage of the Pacific War broke the spell of unassailable military might and cultural domination of the Europeans. Switching to a new colonial master ostensibly belonged to Asiatic orientation, the Malayan people clung to the hope of prosperity and their longing for independence gained strength. This initial euphoria boded ill and short-lived when the local community became disenchanted with soon ensued grim realities of war. Following the Japan's decision to surrender in mid-August 1945, its military operation in the Pacific theatre also came to a standstill.

The end of the Second World War left Malaya in a state of anarchy and defenseless Malayan people against communist guerrillas, not to mention the feeble struggle for independence and freedom. Despite the unsuccessful struggle for Melayu Raya (Greater Malaya) by radical nationalist Malays, the Japanese occupation had marked a crucial point in the development of Malay nationalism. The promulgation of its wartime propaganda to restore "Asia for the Asiatic" by eradicating Western imperial powers from the "Greater East Asia Co-Prosperity Sphere" and leading to the global unification under one divine sovereign "Hakko Ichiu", had a considerable impact on Malayan political development. The occupation accelerated the drive towards Malayan independence amid repeated racial clashes. 
Japan, in its earnest effort to nipponize Malayan population with Japanese-oriented moral principles and ideological precepts, necessitated its military administration to contemplate every possible means soliciting support for the war, instilling Japanese spirit, and more importantly, keeping the new subjects into submission. To this end, Japanese administration incorporated the use of education system and mass media (Kratoska, 1998), Islamic religion, politico-religious elite and Islamic edifices (Abu Talib Ahmad, 1995, 2003), Malay radicals through KMM (KesatuanMelayu Muda or Young Malay Union) (Soh, 1999), and traditional Malay elite who discontent at ineffectiveness of British rule (Stockwell, 1979) within its wartime propaganda machinery.

The nipponization of local community through Japanese propaganda machinery to stir up PanAsiatic spirit, which was distinctly Japanese essence found its profound nationalist manner in Nihonjinron, a popular essentialist view of Japanese-ness. Unravelling Nihonjinron discourse which the Japanese nationalist doctrines inherent is the central aim of this conceptual paper. The paper hasthree sections. The first section deals with the Nihonjinron cultural discourse, the second section presents Nihonjinron as a matter of survival, while the last section includes Japanese ideological propaganda machine. The significance of this study lies in its effort to offer an alternative way of interpreting Japanese occupation of Malaya from the perspective of Nihonjinron. It has important implications for understanding how the construction of Japanese image affects its relationship with Malaysia in the post-war period.

\section{THE CONCEPT OF NIHONJINRON}

Nihonjinron, which literally means theory of the Japanese, accounts for the essential qualities of being the Japanese, unmatched by any other non-Japanese cultures. It is also known as Nihonron (theory of the Japan), Nihonshakairon (theory of the Japanese society), and Nihonbunkaron (theory of the Japanese culture). These various terms have been used interchangeably in Japanese cultural studies by academics and laypeople with the same objective of explaining the characteristic traits that make up Japanese society, culture, personality, and even Japan itself. For this study, the term Nihonjinron is used given its popularity and growing recognition in this subject area. It is not a new phenomenon, but writers of Nihonjinron almost certainly come to agree that it has mushroomed in post-war Japanese Archipelago when full-scale economic recovery and social transformation were afoot.

Nihonjinron has appeared in Japan some point in the far-off past. Befu (2001) points out the budding Nihonjinron grew at the late Tokugawa period when Japan was keen to emulate the sophisticated religion and philosophy, cultural values, and advanced techniques imported from China. Later, the shift from Sinocentric to the Western-centered civilization predisposed the Japanese to admire things Western, be it military, economic, scientific progress, education system, system of government, and universal principles. The prevailing slogan of "enlightenment and civilization" (bunmeikaika) during the Meiji period revealed the rapid modernization program in Japan was Western in origins. Being the most Westernized Asian country and the only non-Western modernized nation, Meiji Japan found itself bogged down with ideological crisis and confused state of civilization. It was struggling to find the way out of the dilemma of choosing between Japanese tradition and European rational knowledge.

Given the embryonic development of Nihonjinron discourse in the late nineteenth century and the subsequent proliferation in 1960s (Befu, 2001), the overwhelming interest of the Japanese in the production and consumption of Nihonjinron thesis was far from being decline, thus earning a reputation as a "national sport", "favorite game" or "national pastime" in Japan (Befu, 1990, 2001; Manabe, 1992). This phenomenon of Nihonjinron sweeping over Japan was attributable to its being the solitary thesis hitherto. When Japan was establishing more and more contact with the outside world, there was no other comparable ideology of the nation dealing with self-identification. The magnitude of Nihonjinron, according to Befu (1984, p. 174), "presents the hegemonic ideology of the nation: there is no other ideology in Japan which can rival it in terms of prevalence, popularity and acceptance by the populace." The author (2001) later observes post-war Japan in need of something to fill the symbolic vacuum left by the demise of wartime militaristic nationalism and the entry of Nihonjinron was right on time. 
The acceptance of this subject is not only limited to academia but also a surge in public demand, leading to virtually possible for all Japanese to be producers and consumers en masse. In a list of Nihonjinron writings compiled by the Nomura Research Institute in 1978, the number has reached 700 titles in the succeeding two decades' post-wartime. Certainly, the number by now has far exceeded the estimate of 1,000 (Manabe \&Befu, 1992). One must not lose sight of avid non-Japanese scholars and their in-depth studies of the Japanese social-cultural milieu, a force to be reckoned with thus far. American anthropologist, Ruth Benedict (1946) and her influential classic work "The Chrysanthemum and the Sword: Patterns of Japanese Culture" which was published in the immediate post-wartime, spearheaded the cultural studies many decades since. Also, Professor of Harvard University, Ezra F. Vogel (1979) who was astounded by the Japanese successes more than three decades ago, in his best-selling book "Japan as No. 1: Lessons for America" detailing the success story of the land of rising sun that was worth of emulation for Japan's counterpart, the U.S.

At the crux of Nihonjinron analysis, it lies the notions of essential "Japaneseness" (Sugimoto, 1999) or quintessential "Japanliness" (Befu, 2001), a host of cultural values that the Japanese are susceptible to. This ideal spirit of "Japaneseness/Japanliness", which in stark contrast to other cultural value systems, has a bearing on myriad aspects of Japanese life. Proponents of Nihonjinron come to concur with the fundamental assumptions of "Japaneseness/Japanliness" on the following three points. First, Japan is a distinctly unique society and Japanese are a homogenous people in terms of the language, physical appearance, race, bloodline, tradition, beliefs, and practices they share. Second, it is hardly to imagine that non-Japanese are adept at comprehending Japan's culture because solely Japanese understand what it is being Japanese. Third, Japan's conflicting perspectives between self and other, in this case the dominant Western culture.

By accentuating the singularity of Japanese culture, society, and national character per se, Nihonjinron analysis is likely to have a bias outlook, regardless of social differences in Japanese society. Stereotyping Japanese mode of behavior and way of thinking in a uniform fashion, this popular cultural discourse is composed chiefly of cultural nationalism or ethnocentrism (Befu, 1984, 1990, 2001; Manabe, 1992). While certain aspects of the cultural discourse hold true, it is in fact a smokescreen that masks Japan as a diverse society altogether. Using the equation of nationality=ethnicity=culture in making sense of Nihonjinron, Sugimoto (1999, p. 83) notes, "[...] the Nihonjinron cultural analysis can and does operate like a facade used to conceal nationalistic and/or racial doctrines that it embodies."

In this context, it is unsurprisingly that the Japanese authorities and business elite take the Nihonjinron logic well and internalize the essential view of Japanese culture to articulate representation of Japanese image globally. The immense energy and money the country has invested in advocating a positive image of Japan overseas spells out cultural diplomacy instrumentally valuable to the establishment in projecting "real Japan's image". Notably since 1980s, the vigorous campaign of Japanese culture under Ohira's administration followed by the founding of International Research Centre for Japanese Studies under Nakasone's administration (Befu, 2001; Sugimoto, 1999) further attest to political endorsement of Japanese cultural nationalism. The widespread endorsement of Nihonjinron thesis by every stratum of society seemingly caters to the beneficiaries' every need. As pointed out by Befu (2001, p. 81), "[the] intellectuals write Nihonjinron as prescription for behavior. The government turns it into a hegemonic ideology, and the corporate establishment puts it into practice."

\section{NIHONJINRON A MATTER OF SURVIVAL}

Japan's dichotomous views of "Others" in a long continuum of foreign cultures form along the duality of Orientalism of the Occident (Said, 1978) and Occidentalism of the anti-Occident (Buruma\& Margalit, 2004). The world is divided simply because of the ubiquitous prejudiced view in which the West created the East as inferior "Other" and the distorted picture of the West painted by the occidentalists. The duo of concepts orientalism and occidentalism are instrumental to justify Japan self-identification in contrast to "Others". 
Following Edward Said's Orientalism, Askew (2004) argues that a superior Japan created a similar but much more complicated orientalist view towards China, perceived as powerless in the face of the West by adopting the line datsu- $\mathrm{A} \mathrm{Nyu-O}$ (leave Asia, join the West), later towards Asian countries depicted as inferior "Other" in need of Japan's intervention through the wartime slogans "Greater East Asia CoProsperity Sphere" and "Hakko Ichiu". The author finds "Japanese Orientalism" a self-contradictory concept because Japan indisputably an Asian country despised other Asian countries, but at the same time internalized orientalism of the West. Befu (2001) labels this process of self-denigration as autoorientalism that took place during the early Meiji period and in the immediate postwar era when the strong feeling of inferiority maneuvered the Japanese to avail themselves of cultural particularism as defensive measure.

On the other hand, Buruma and Margalit (2004) argue that occidentalism was not Muslim world or Japanese born and bred, but its historical root was traceable to Europe, identical to the birth of industrial revolution, Enlightenment, and many other modern ideas, before travelling to other parts of the world. A distaste of the West can be seen in its enemies' reactions against the sinful City of Man, unheroic merchants, rationalism of the mind of the West, and worshipping the false god of matter which might be sowing the seeds of revolution. The Japanese were deeply influenced by German-style ethnic nationalism and applied their occidentalist prejudices to Japan and other Asian countries with claim of modern progress and enlightened races unbound by Western imperialism. Japanese frenzied nationalism had much to say about the suicidal attacks committed by kamikaze pilots and banzai raids.

In the late eighteenth and early nineteenth century, the budding Nihonjinron derived its inspiration from the intellectual source of Kokugaku (national learning) scholarship, explicitly to set Japan free from the obstruction of Kangaku (Chinese learning) and Confusion works. Under the dominating influence of China as discerned from the importation of the religion of Buddhism and moral philosophy of Confucianism, the Sino-centric civilization has been a great concern of frustrated Japan. The latter found itself wrestling with deep sense of insecurity in the asymmetrical power relations with China because Chinese superiority did not sit easily with Japanese native culture. Kokugaku thinkers sought to revitalize indigenous culture in response to a perceived threat posed by China. Hence the nativist movement took form to surmount the problem associated with the weakening Japanese-ness.

The Europeans replaced China in the Meiji period as the role model to look up to. Fear of external invasion and occupation by Western powers, Japan saw no way out but to transform itself after Western model. The worldly achievements can be seen in education reform, capitalist economic system as well as a radical change in political and cultural realm that called for a new notion of nation-state in replacement of feudal structure of Tokugawa Japan. This new sense of the nation was established through the creation of state Shinto and mythification of the Emperor (Askew, 2004), which formed the core wartime ideology until the end of Pacific War. Nevertheless, the ephemeral adoration and emulation of things Western sparked off the chasm between ancient Japanese tradition and Western rationalism. Japan's successive victories with China and Russia may show its new great power relations with the leading imperial powers. But that has not proved to be the case. Japan's new sense of civilization which was colored by Western modernization led to the former otherworldly ideals to be faded into oblivion. As the matter of fact, Western deep-seated orientalist view did not accommodate Imperial Japan's new emerging power status.

As postwar Japan moved into the West-dominated globalized world, particularly the U.S. with whom Japan's future rests on, the dominance of Western culture created an identity crisis among Japanese yet again. However, the problematic wartime national symbols coupled with the heightened sense of antiwar drive "contemporary Nihonjinron to strip wartime Nihonjinron of its imperial and militaristic elements and re-dress it in a language devoid of war and militarism" (Befu, 2001, p. 102). If the wartime national symbols have the constraining effect on Japan's behavior by crushing the ideological framework that it might use to advance expansionist aims, it does not stop the establishment from capitalizing on the nationalist manner of Japanese essence to safeguard the status-quo, not to mention a manipulative tool to keep foreign influences at bay. 
To this end, one might ask "is nationalist Japanese-ness a boon or bane for Japan?" The answer to this question has pointed to the pendulum swings between feelings of superiority and inferiority (Reischauer \& Jansen, 1977). Befu (2001) also argues the vicissitudes of Nihonjinron with reference to various reference points at various times of history that have much to do with the inferiority feeling buried in the Japanese mind. It is undeniable that the cultural discourse has waxed and waned with the fluctuations in sense of security planted in the mind of Japanese. External constraints and domestic political factor are the two determinants in assessing national interests with nationalist underpinning. When Japan is consigned to disadvantageous relative power status vis-à-vis other reference points, it tends to discourage nationalist Nihonjinron and vice versa. Japan became jingoistic and more assertive when it was buoyed up by the consecutive military victories over China and Russia in 1895 and 1905. Cultural nationalism was riding high again during its phenomenal economic growth in the 1960s and 1970s. The ups and downs in Japanese-ness are also contingent on domestic political environment and internal changes. The ideological pendulum has been in constant swing between the conservative right and progressive left.

If survival lies at the heart of Japanese national interest, its security can only be assured when the entire Japanese population is mobilized to behave uniformly against a perceived threat. Japan's external behavior has much to do with external constraints along with its domestic political factor. At various times in history, Japan had been living in the shadow of other greater influences though it was one of the Asian countries free from European colonial domination. While Japan as the principal debtor discontented at the asymmetrical relations with the creditor with whom it borrowed culture intensively and re-produced its own civilization, the fluctuations in sense of security have dictated its nationalist drive for protection or expansion. To this end, power is the most important asset that lies at the survival of nation, be it militaristic or non-militaristic form. In the event of Japan's survival is assured, it can pursue other goals to extract more power in its favor. When shaken sense of security planted in the mind of Japanese particularly in the immediate post-war period, nationalist Japanese-ness becomes negligible as it has lost the galvanic effect to mobilize a homogenous cultural identity.

\section{JAPANESE IDEOLOGICAL PROPAGANDA MACHINE}

The Imperial Japanese forces successfully conquered the whole Malaya and Singapore in less than two and a half months since its landing on Singora and Patani of Southern Thailand and Kota Bharu, Malaya on December 8, 1941. Japan's swift and decisive occupation of Malaya and Singapore revealed British army was ill-prepared vis-à-vis battle-hardened Japanese troops. Similar in predatory appearance to European colonial powers, Japan was an imperialist in fact, subjugated the inhabitants to its wartime needs. Japan, in its great effort to nipponize Malayan community with Japanese-oriented moral principles and ideological precepts, necessitated its military administration to contemplate every possible means soliciting support for the war, instilling Japanese spirit, and most importantly, keeping its new subjects into submission. Wartime propaganda machinery was instrumental to Japanese military rule that would correct English-like local political sentiment and way of life by acquiring Nippon spirit and culture, of which had enabled Japan to become one of the great powers, the high status and prestige of which the Japanese believed were not the exclusive rights to Western powers.

The Japanese military regime had embarked on indoctrination effort by extending its tentacles to anti-British Malay leftists in fifth column activities from the beginning of the invasion, and later the effort was stepped up and expanded not just through education system, but also the mass media (Kratoska, 1998). These Japanese sponsored propaganda machineries repeatedly glorifying warrior class ethos in the form of mental and physical training which had permeated ancient samurai society and as a key factor in molding Japanese mind and character. The crucial ideological justification of creating Pan-Asiatic identity and structuring new order in "Greater East Asia Co-Prosperity Sphere" was to bring the Malayan community in accordance with Nippon spirit, which has derived inspiration from Buddhist practices, Confucian concepts, and ancient Japanese beliefs. 
Realizing the Malayan populace were accustomed to Western way of life, the exigency called on the Japanese to transform Malayan society by banning English and Chinese as language instruction in the school system.Japanese language (Nippon-go) was introduced in replacement of those languages of the enemies. The Japanese language was not only used to facilitate daily communication but also a valuable tool to inculcate Nippon spirit and cultural values into the indigenous community. Under the heavy scrutiny of Japanese military regime, the school curriculum was revised that consistently in line with the Japanese ideological slant to get rid of contaminated Western ideas. As Kratoska (1998, p. 122) observes, "the new spirit of Asia was the Japanese spirit, the prospective lingua franca for the region was the Japanese language."

Given the local Chinese were the prime targets of Japanese hostility, the ban on Chinese language was understandable. However, the Sino-Japanese mutual hostility had become a major stumbling block due to not the whole Malayan community bought into Japan's grand strategy of the establishment of new order in the region. Restriction of the imported Chinese publications would only lead to the towering rage and already-worsening relationship to deteriorate further. Japanese language learning was also popularized with the help of mass media. Not only school children and local teachers, the public were urged to realize the importance of Japanese language in bolstering Pan-Asiatic identity and forging Asian unity.

In local administrative matters, Japanese language was used widely instead of Malay language. In Leadership Training School (Koa Kurenjo), Japanese language was taught apart from Japanese spirit. Notably, the establishment of Koa Kunrenjo was aimed at pathing the way for Malay youths to enter public service. In tandem with Nippon language lesson, students were imparted Japanese spirit through assorted mental and physical exercises (Abu Talib Ahmad, 2003). By undergoing the rigorous spiritual and physical teachings, one can align himself with the peculiar spirit of Japanese-ness by displaying the virtues of hardworking, cooperation, endurance, discipline, loyalty, and valor. Having attained Japan's spirit, one can endure all kinds of hardship and adhere to "self-sacrifice rather than dishonor" principle that accorded with the warrior's code of the Japanese militaristic ruling class.

At schools, as part of highly regimented school life, students were to observe daily rituals by taking part in the ceremony of hoisting Japanese flag, singing Japanese anthem, facing the direction of Imperial Palace, making a deep bow, and performing physical exercise (rajiotaiso) (Abu Talib Ahmad, 2003; Kratoska, 1998). School employees including teachers were to partake in the ceremony to show reverence for Japanese sacred sovereign. Civil servants working in various government agencies were not kept out of the regimented daily routine as well. The Japanese regime also incorporated Japanese and Malay patriotic songs in school curriculum as well as propaganda activity conducted by Japanesesponsored paramilitary forces that intended to glorify Japanese greatness and instill Nippon spirit and to despise the British (Abu Talib Ahmad, 2003). Physical training in the form of Japanese popular sports was also integral to the praiseworthy manner of self-discipline and self-restraint to overcome the hardship.

Equally important was the celebration of Japanese holidays and anniversaries in which local community was compelled to participate in these ceremonies and observed them with a great deal of respect. Of most important are the celebration of birthday of the Emperor of Japan on April 29, anniversary of the Greater East Asian War (December 8), and the celebration of Japanese victory over British forces (February 15). Government officials, representatives of major ethnic communities, and the public were to participate in the ceremonial occasions by honoring Japan's glorious effort of expelling Western enemy under the Imperial benevolence. The Japanese regime also sought to galvanize the public into showing continued loyalty and infinite support to win the war against Western power in Asia. Abu Talib Ahmad (2006) in his visit to Penang State Museum found that a total of 21 commemorative holidays were celebrated during Japanese rule in Malaya. The author (1995, 2003, 2006) contended Japanese maneuver by incorporating religious elite and mosques/surau into the Japan's propaganda activity including the celebration of the occasions had indeed nothing to do with the latter. Such manipulative move towards the Japanese war effort was in which neither Muslims nor Malay-Muslims had any vested interest. 


\section{CONCLUSION}

Today, Japanese society is swiftly changing. The problematic wartime ideology and nationalist frenzy have been reduced to a more apologetic and self-critical tendency. Nevertheless, the idea of imperialism is much alive and well in the age of globalization when American cultural production is encroaching on the rest of the world with its universal secular principles. Japan is no exception when it embraced a globalized overview in the 1970s through the notion of kokusaika (internationalization). Though Japanese identity has become more positive and assertive given its economic growth and pacifist outlook, the growing uneasiness with the overarching Western dominance compels Japan to adopt the process of internationalization of its own. This is a defensive way to ensure Japanese national interests and cultural identity are well-preserved in the global arena (Turner, 2013).

Nihonjinron is a civil religion for the Japanese, as argued by Befu (2001). It is not an exaggeration to say that the post-war de-militaristic cultural discourse is, among other things, the alternative therapy that has the healing power by restoring Japanese faith in its cultural and spiritual origins, at least in the case of Japan's uncertain position in the changing global economy and geopolitical landscape. The cultural discourse has sought to address Japanese cultural identity crisis and serves as ways to produce the peculiar Japanese-ness spirit in terms of national ideology, cultural distinctiveness, and ethnic solidarity. As the matter of fact, survival lies at the heart of Japanese national interest. Its security can only be assured when the whole Japan's peoples were to be mobilized to act and think in a homogenous manner against the perceived threat. Soft power is most likely the best means to postwartime Japan in reshaping its image abroad as well as reasserting power at home.

The history abounds with all sorts of propagandist activities, as in the case of Japan's nipponization program in occupied Malaya. Learning the Japanese spirit and molding the occupied peoples to Japanese way of thinking and behavior mode were the grand strategy of new colonizer of the establishment of new order in "Greater East Asia Co-Prosperity Sphere". Today, the more assertive Malaysia is bound and determined to "Look East" by the recognition of Japanese economic leadership and extraordinary accomplishment despite the unpleasant experiences of Japanese militaristic occupation. It was the fourth Prime Minister, Dr. Mahathir that pioneered the Look East policy in the early 1980s. And later the effort was stepped up and extended under his successors' administrations.

Malaysia is likely to continue with the policy given the ever-increasing interdependency between the two countries economically and culturally. The staging of benign global image, coupled with outstanding economic progress, should make Japan at this moment in time proud of its great accomplishment by generating a favorable impression on Malaysia. According to a Pew Research Center survey, Malaysians generally view Japan more favorably (84\%) than China (78\%). About seven-in-ten Malaysians (73\%) have confidence in Japanese prime minister, Shinto Abe's leadership in dealing with world affairs (Pew Research Center, 2015). The contemporary Nihonjinron that is devoid of militaristic configuration could prove a boon for Japan as it is instrumental in projecting "real Japan's image" as well as maintaining the power of status quo at home.

\section{REFERENCES}

Abu Talib Ahmad. (1995). The impact of the Japanese occupation on the Malay-Muslim population. In P. H. Kratoska (Ed.), Malaya and Singapore during the Japanese occupation (pp. 1-36). Singapore: Singapore University Press.

Abu Talib Ahmad. (2003). Malay-Muslims, Islam and the rising sun: 1941-1945. Kuala Lumpur: MBRAS.

Abu Talib Ahmad. (2006). Museums and the Japanese occupation of Malaya. In R. Mason \& Abu Talib Ahmad (Eds.), Reflections on Southeast Asian history since 1945 (pp. 25-52). Penang: PenerbitUniversitiSains Malaysia.

Askew, R. K. (2004). The cultural paradox of modern Japan: Japan and its three others. New Zealand Journal of Asian Studies, 6(1), 130-149. Retrieved from www.nzasia.org.nz/downloads/NZJAS-June04/6_1_7.pdf 
Befu, H. (1984). Civilization and culture: Japan in search of identity. Senri Ethnological Studies, 16, 59-75. https://doi.org/10.15021/00003308

Befu, H. (1990). Dimensions of cultural nationalism. In Proceedings of the Seoul Olympiad Anniversary Conference Seoul, Korea.

Befu, H. (2001). Hegemony of Homogeneity. Melbourne: Trans Pacific Press.

Benedict, R. (1946). The chrysanthemum and the sword: Patterns of Japanese culture. Boston: Houghton Mifflin.

Buruma, I. \& Margalit, A. (2004). Occidentalism: The West in the eyes of its enemies. New York: Penguin Books.

Kratoska, P. H. (1998). The Japanese occupation of Malaya, 1941-1945: A social and economic history. London: C. Hurst \& Co. (publishers) Ltd.

Manabe, K. (1992). Japanese cultural Identity: Old tradition, new technology. Sociology Department Studies (KwanseiGakuin University), 66, 119-122. $\quad$ Retrieved from https://www.kwansei.ac.jp/s_sociology/kiyou/66_jp.htm

Manabe, K.\&Befu, H. (1992). Japanese cultural identity: An empirical investigation of Nihonjinron. Japanstudien, 4, 89-102. https://doi.org/10.1080/09386491.1993.11827036

Pew Research Centre. (2015). How Asia-Pacific publics see each other and their national leaders. Retrieved from: http://www.pewglobal.org/2015/09/02/how-asia-pacific-publics-see-each-other-and-their-national-leaders/ [Accessed 29 November 2018].

Reischauer, E. O. \& Jansen, M. B. (1995). The Japanese today: Change and continuity. Cambridge: Belknap Press.

Said, E. W. (1978). Orientalism. New York: Vintage Books.

Soh, B. (1999). Some questions about the impact of Japanese occupation (1942-45) on the development of Malay nationalism: With special reference to the KesatuanMelayu Muda. International Area Studies Review, 2(1), 19-42. https://doi.org/10.1177/223386599900200102

Stockwell, A. J. (1979). British policy and Malay politics during the Malayan Union experiment 1942-1948. Kuala Lumpur: MBRAS.

Sugimoto, Y. (1999). Making sense of Nihonjinron. Thesis Eleven, 57, 81-96. https://doi.org/10.1177/0725513699057000007

Turner, B. S. (2013). The religious and the political: A comparative sociology of religion. New York: Cambridge University Press.

Vogel, E. F. (1979). Japan as number one: Lessons for America. Cambridge: Harvard University Press. 